\title{
EU-Canada Strategic Partnership: Ups and downs
}

\author{
AMY VERDUN ${ }^{1}$ \\ Leiden University, The Netherlands and University of Victoria, BC, Canada \\ a.c.verdun@fsw.leidenuniv.nl
}

\begin{abstract}
Signed in 1976, the EU-Canada relationship was the first bilateral agreement that the EU signed with an industrialised third country. Modest strengthening of the ties was achieved with the 2004 EU-Canada Partnership Agenda. A fully-fledged free trade agreement was in the works at this time, but suspended in 2006. The EU-Canada strategic partnership agreement (SPA) and the Comprehensive Economic Trade Agreement (CETA) did not materialise until more than a decade later, in 2016. This paper focuses in particular on the strategic partnership dimension. It explores why an SPA was possible in 2016, but not before. To answer this question, the paper looks at four time periods. In so doing it explores the origins of the EU-Canada agreement, how the EU-Canada relationship changed over time, and examines how a more profound strategic partnership came about when it did. In its analysis it considers institutional, domestic and geopolitical factors. It briefly speculates about the possible future of this partnership.
\end{abstract}

Key words: Canada, EU, EU-Canada strategic partnership agreement, Transatlantic Relations

\section{Introduction}

The European Union (EU) ${ }^{2}$ and Canada signed a strategic partnership agreement (SPA) on 30 October 2016. It provisionally entered into force on 1 April 2017 (European Union, 2017). This paper studies the origins of this agreement and examines how the EUCanada relationship in this regard changed over time. It explores why an SPA was possible in 2016, but not before. In this paper I divide up EU-Canada collaboration into four time periods: period one (from 1959-1976); period two (1977-1996); period three (1997-2008); period four (2009-present).

The Canadian agreement with the EU is an important one. Signed in 1976, the 'Framework Agreement for Commercial and Economic Co-operation between the European Communities and Canada' was the first bilateral strategic partnership that the

\footnotetext{
${ }^{1}$ An earlier version of this paper was presented at the International Workshop Jean Monnet Network on EU-Canada Relations: The EU and Canada in Dialogue "New Opportunities for the EU-Canada Strategic Partnership", 8 November 2019, TU Darmstadt, organised by Michèle Knodt, Technical University Darmstadt, and Natalia Chaban, University of Canterbury, Christchurch. The author thanks Sharon Pardo, Godelieve Quisthoudt-Rowohl, Antoine Rayroux, the other workshop participants and the editors of the special issue for comments on an earlier version of this paper. She also thanks Fengan Jiang (Richard), PhD candidate at the Europa Institute of Leiden University, Gordon S. Smith, and an anonymous reviewer of the journal for comments on an earlier version of this paper. The usual disclaimer applies.

${ }^{2}$ For simplicity, I use 'European Union' or 'EU' to refer to the actual EU as well as to the earlier 'European Communities' or 'European Community'.
} 
EU signed with an industrialised third country. Modest strengthening of the ties was achieved in 1990, 1995 and 1996 and also with the 2004 EU-Canada Partnership Agenda (DeBardeleben and Leblond, 2010). However, a fully-fledged free trade agreement let alone a strategic partnership remained elusive for some time. Ultimately, however, the Comprehensive Economic Trade Agreement (CETA) and the SPA were both signed on the same date. 3 Although at the time of writing their full ratification is not yet complete, the EU-Canada relationship has been further strengthened by having these agreements provisionally enter into force.

This paper examines the following question: why was this more institutionalised collaboration possible to be signed in 2016, but not before? This paper seeks to address this question by assessing the path of the creation of the strategic partnership agreement: why has the deepening of the EU-Canada strategic partnership been a challenge to set up in the first three decades after having signed early institutional structure provided by the 1976 agreement. To assess this process the paper seeks to understand the role of governance structures of both partners as well as the strategic opportunity that came out of the agreement. The existing literature suggests that earlier cooperation in this domain failed for two reasons. First, in the earlier time period, both Canada and the EU did not think that the partnership was as important. Instead, Canada was mostly oriented towards the United States (US) and the same held for the EU. Neither saw a need to 'go around' the US in terms of developing relationships with each other that would not be reproduced by the other transatlantic partner. Most of the early period was characterised by the Cold War with both parties being in the North Atlantic Treaty Organization (NATO) which provided a strong security umbrella. Furthermore, internally the EU was institutionally not very strong and security as a policy area was not well developed at the EU-level. Each of the parties was also caught up with its own internal issues. On the Canadian side, the early years were coloured by issues such as the Quebec referendum, the creation of the North American Free Trade Agreement (NAFTA) but also the fisheries war (Crowley 2004). On the European side, the first two decades, internal European integration was more developed in the area of agriculture, commerce, and trade matters rather than on security and defence matters. Thus, in addition to not having a clear sense of its strategic goals, the EU did not yet 'speak with one voice' on these more external political matters (Potter, 1999; Long, 2003; Barry, 2004; BernardMeunier, 2006; Croci and Verdun, 2006; Haglund and Mérand, 2010; Mérand and Vandemoortele, 2011). Second, there was also a lack of appreciation of the multilevel governance and federalist institutional set-up on both sides (Haglund, 2000; Benz, 2010; Verdun and Wood, 2010). The European Union did not understand fully how decentralised the Canadian federation was; the Canadians, in turn, for many years lacked a solid understanding of the institutional set up of the European Union. As a result, Canadian diplomats were more inclined to look to European member states separately and bilaterally rather than deal with the EU as a collective. The present paper seeks to re-assess these two insights from the literature in light of the recently signed SPA agreement with a view to obtaining a better insight as to why the agreements could be completed this time compared to the failed attempts (or weak arrangements) earlier.

The second goal of this paper is to understand why the eventual combination of the CETA and the SPA became the most comprehensive agreement between the EU and Canada to date, including many different dimensions (political, economic, strategic,

3 https://pm.gc.ca/en/news/statements/2016/10/30/eu-canada-summit-joint-declaration 
security, judicial, environmental and social)? Were there any set-backs and if so how can we best understand those disruptions? Part of the reason to explain this relationship must be found in the following factors: an assessment of the costs and benefits of the type of relationship between Canada and the EU, the perceived role of the United States (US) and the global arena, and the need mutually to understand the institutional structure of governance of both partners.

The remainder of the paper is structured as follows. The next section looks at the literature of the Canada-EU relations with a particular focus on the Strategic Partnership Agreement. The third section provides an empirical case study of the Strategic Partnership, offering an analysis of this case study. The fifth section concludes.

\section{What is the Canada EU Strategic Partnership agreement? A review of the literature on the Canada-EU relations}

In what follows I provide a brief review of the literature that discusses the strategic activities developed between Canada and the European Union. I have grouped these agreements into four time periods: period one (from 1959-1976); period two (19771996); period three (1997-2008); period four (2009-present).

Table 1: Canada-EU Agreements (1959-2016) (selection)

\begin{tabular}{|c|c|c|c|}
\hline Date & Name & $\begin{array}{l}\text { Sectoral } \\
\text { Agreement }\end{array}$ & $\begin{array}{l}\text { Framework } \\
\text { Agreement }\end{array}$ \\
\hline 1959 & $\begin{array}{l}\text { Agreement between the Government of Canada and the } \\
\text { European Atomic Energy Community (EURATOM) for } \\
\text { Cooperation in the Peaceful Uses of Atomic Energy }\end{array}$ & $\mathrm{x}$ & \\
\hline 1976 & $\begin{array}{l}\text { Framework Agreement for Commercial and Economic Co- } \\
\text { operation between the European Communities and Canada }\end{array}$ & & $\mathrm{x}$ \\
\hline 1990 & 'Declaration on European Community-Canada Relations' & & $\mathrm{x}$ \\
\hline 1991 & $\begin{array}{l}\text { Agreement on nuclear co-operation (amendment of the } \\
1959 \text { agreement) }\end{array}$ & $\mathrm{x}$ & \\
\hline 1995 & $\begin{array}{l}\text { 'EU-Canada Agreement on Higher Education and Training } \\
\text { (renewed in 2000) }\end{array}$ & $\mathrm{x}$ & \\
\hline 1996 & 'Joint Political Declaration on EU-Canada Relations' & & $\mathrm{x}$ \\
\hline 1996 & 'Joint Canada-EU Action Plan 1996’ & & $\mathrm{x}$ \\
\hline 1996 & Agreement on Scientific and Technical Cooperation & $\mathrm{x}$ & \\
\hline 1996 & $\begin{array}{l}\text { Agreement for the conclusion of negotiations between } \\
\text { under GATT Art XXIV: } 6\end{array}$ & $\mathrm{x}$ & \\
\hline 1997 & $\begin{array}{l}\text { Agreement on international humane trapping standards } \\
\text { (with the Russian federation) }\end{array}$ & & \\
\hline 1998 & $\begin{array}{l}\text { Agreement on Customs Cooperation and Mutual Assistance } \\
\text { in Customs Markets }\end{array}$ & $\mathrm{x}$ & \\
\hline
\end{tabular}




\begin{tabular}{|c|c|c|c|}
\hline 1998 & $\begin{array}{l}\text { Agreement on Sanitary Measures to protect public and } \\
\text { animal health in respect of trade in live animals and animal } \\
\text { products }\end{array}$ & $\mathrm{x}$ & \\
\hline 1999 & Agreement regarding the Application of Competition Laws & $\mathrm{x}$ & \\
\hline 2004 & $\begin{array}{l}\text { Agreement concerning trade and commerce in alcoholic } \\
\text { beverages }\end{array}$ & $\mathrm{x}$ & \\
\hline 2004 & EU-Canada Partnership Agenda & & $\mathrm{x}$ \\
\hline 2005 & $\begin{array}{l}\text { Agreement establishing a framework for the participation of } \\
\text { Canada in the EU crisis management operations }\end{array}$ & & $\mathrm{x}$ \\
\hline 2009 & 'Air Safety Agreement' & $\mathrm{x}$ & \\
\hline \multicolumn{4}{|c|}{$\begin{array}{l}\text { All agreements are between the Government of Canada and the European Communities unless specified } \\
\text { otherwise. } \\
\text { Sources: Commission of the European Communities (2003): 16-17; Mahant 1985, various other sources. } \\
\text { See also: ec.europa.eu/trade/issues/bilateral/countries/canada/index_en.htm; https://nuclearsafety.- } \\
\text { gc.ca/eng/resources/international-cooperation/international-agreements.cfm\#Euratom } \\
\text { http://ec.europa.eu/world/agreements/searchByType.do?id=1 }\end{array}$} \\
\hline
\end{tabular}

1959-1976: In the first period we find the agreement that was signed between the European Atomic Energy Community and Canada in 1959. Together with the agreement with the US (signed in 1958) it was the first such accord and it ends with the signing of the 1976 agreement. The early work focuses on the 1976 agreement (cf. Mahant, 1981). It provided structure for dialogue. A Joint Cooperation Committee (JCC) was to meet annually 'to promote and keep under review the various commercial and economic cooperation activities'. Towards the end of this period scholars wrote about Canada's policy towards the rest of the world using the terminology of 'third option', meaning to steer away from an overly strong reliance on the US (Mace and Hervouet, 1989).

1977-1996: The second time-period starts with the entry into force of the 1976 agreement, contains the 1990 agreement, 'The Declaration on Transatlantic Relations between the European Community and its Member States and Canada' and the 1995 sectoral agreement on 'EU-Canada Agreement on Higher Education and Training' as well as the 1996 'Joint Political Declaration on EU-Canada Relations'. Edelgard Mahant in an overview of the kind of collaboration that took place right after the signing of the 1976 agreement 4 till the mid 1980s, provides a useful overview of what has happened in the first decade. She identifies that most of the 'high level' meetings are in fact not at the highest level but rather at the level of the assistant deputy minister (Canada) and deputy director-general (Commission). Mahant characterises this level as "the meeting point between the political and the 'official' levels... too low a level to deal with basic political issues but at too high a level to negotiate the details of the trade and scientific cooperation which are the day-to-day subjects of Canada-Community discussions." (Mahant, 1985, p. 286). She also describes the annual meetings of the parliamentary delegations of European and Canadian parliaments during this time. She lists various subcommittees that have met during the period, such as the industrial co-operation

\footnotetext{
${ }^{4}$ Mahant (1985: 285) reports that the 'Semi-Annual' or 'High levels' meetings started to take place already before the 1976 namely, since the 1972 informal Canada-European Community Agreement although the meetings did not take place twice a year in every year (both in 1974 and 1977 only one such meeting took place).
} 
subcommittee' and the 'preparatory and general co-operation subcommittee'. A highlight of this period was the signing of the 1990 political declaration but the remainder of the 1990 s did not generate major initiatives in bilateral cooperation. Charles Pentland identifies Canada's response to renewed process of European integration process, as the cold war was coming to an end, as "the most far-reaching challenge to Canada arising from the post-war unification of western Europe" (Pentland, 1991) There were, however, numerous smaller, sectoral, agreements between Canada and the EU (see Table 1). Furthermore, cooperation took place within other international organisations. This piecemeal approach was the best that could be arranged during this time. These smaller steps should, however, not be underestimated. The final part of this second period is characterised by fishing sector wars. At this time Canada and the EU were having numerous issues around fishing in the North Atlantic (Barry, 1998) with Canada eventually sending warships to try to address the issue of Portuguese and Spanish fishermen alleged overfishing and violating international agreements on the quantity and size of fish. The strategy chosen was confrontational but aimed at forcing the issue to the top of the agenda by using rogue strategies (Missios and Plourde, 1996). Though it resolved the matter in Canada's favour, it cost the country considerably in terms of hurting diplomatic relations (Howe and Kerby, 20095). Nevertheless, as mentioned above, the two sides did manage to sign the 1996 'Joint Political Declaration on EU-Canada Relations'.

1997-2008: During the third period Canada started to put the EU more centrally on the foreign policy agenda (Potter, 1999, p. 1). It chose the bilateral agreement system whereby different sectoral issues were chosen as a path forward. For instance, in 1996 both parties signed an Agreement for Scientific and Technical Cooperation. In the same year they also concluded an Agreement for the conclusion of negotiations under GATT Art XXIV:6. Furthermore they also cooperated together with a third party (the Russian Federation) international humane trapping standards (in 1997). Two other agreements were signed in 1998, one in the area of Customs Cooperation and Mutual Assistance in Customs Markets and another Agreement on Sanitary Measures to protect public and animal health in respect of trade in live animals and animal products. A year later, in 1999, they signed an Agreement regarding the Application of Competition Laws. In 2004 they signed another sectoral agreement that focused on single market issues, namely the Agreement concerning trade and commerce in alcoholic beverages. This period was closed with an important step forward on various issues that were bundled together under the 2004 EU-Canada Partnership Agenda. A year later both parties signed the Agreement establishing a framework for the participation of Canada in the EU crisis management operations (2005). All in all, there were many sectoral agreements but an overarching free trade agreement proved difficult.

2009-present: This period started off with another sectoral agreement, namely an EUCanada 'Agreement on civil aviation safety between the European Community and Canada' (2009). Shortly after it became clear that the EU and Canada could collaborate on a free trade agreement and possibly a strategic partnership agreement if they embarked on the negotiations in a more bottom up fashion, in particular on the Canadian side. Earlier attempts to have a free trade agreement suffered on the Canadian side by having been conducted only at the federal level without including lower level partners such as the provinces and territories. The Europeans were surprised that it was

\footnotetext{
${ }^{5}$ Gordon S. Smith, who was involved in these fishwars as deputy minister of Foreign Affairs, characterised Canada's stance as forceful. He said it was necessary to do something (Author's interview 11 December 2019).
} 
so difficult in Canada to have federal level bodies negotiate on behalf of the lower governance levels in Canada. The negotiations were very trying but eventually they pulled off a comprehensive economic trade agreement and the strategic partnership agreement and both were signed on the same date in 2016.

\section{Case study of the Strategic Partnership}

Mérand and Rayroux (2018, pp. 189-194) identify three main debates within the EU about how the EU seeks to deal with its foreign relations vis-à-vis the rest of the world. These three debates shed light on how the EU-Canada agreements fit within the EU internal considerations. The first debate concerns the extent to which the large EU member states have more influence over EU foreign policy compared to the smaller ones. The second is whether all of the member states would participate in all EU actions. The EU consists of members with different interests, some are neutral or may have different relations with countries outside of the EU (due to their different historical past with countries external to the EU). The third is the extent to which the EU should remain focused mostly on 'soft power' or whether it needs to move towards becoming a stronger military actor. The negotiations between Canada and the EU covered all three of these debates.

Canadian foreign policy has traditionally been in line with its main allies (the US, Europe) and heavily oriented towards multilateralism. Over time, it has become more assertive and started to consider to what extent Canadian Foreign Policy would be different from heavily relying on the US. When Robert Kagan famously argued in 2002 that the transatlantic drift of the turn of the century could be seen as the Europeans being from Venus and the Americans from Mars, it hit a nerve in the Canadian context (Long, 2003; see Kagan, 2003). At the start of the negotiations that would lead to the SPA and CETA eventually signed in 2016, the EU had become a much more important potential partner to Canada than before (Haglund and Mérand, 2010). Both parts had also learnt about the importance of appreciating the difficulties of negotiating with loosely federated systems (Benz, 2010). In the run-up to the negotiations, Canadian elites considered numerous international threats that were in need of attention.

In a paper analysing the threat perceptions of Canadian political, bureaucratic and academic security elite, as compared with those articulated by the Canadian government based on a survey results with bureaucrats and foreign policy experts, they found that the EU was perceived to be important to solve the most salient foreign policy issues of the day but not absolutely crucial (Tossutti, Croci and Verdun, 2007). Experts also still look more towards the US for support than across the Atlantic.

The negotiations for the Strategic Partnership started only in September 2011 at the same time as those for CETA. Here the premise was that the 1976 EU-Canada framework agreement had become ineffective due to the many changes in the bilateral relations that had emerged since its signing in the mid 1970s. Also, the entry into force of the Lisbon Treaty enabled the EU to be better prepared, institutionally, in dealing with foreign relations (with the European External Action Service having been created). European Commission President José Manuel Barroso and Canadian Prime Minister Stephen Harper announced in the spring of 2014 that an agreement in principle had been reached, in the margins of a summit that took place in The Hague (Gardner, 2014). Three years later, in September 2014, various media signalled that the EU and Canada were closer to reaching an agreement (Gardner, 2014). It was formally adopted by the 
European Commission in April 2015 and signed by the EU and Canadian leaders at the EU-Canada summit on 30 October 2016. Some of the issues on which progress had been made on the partnership agenda of 2004 was incorporated into this SPA. A new innovation was made here to avoid a deadlock: knowing that ratification could be an obstacle, namely to have some parts of the SPA enter into effect even before full ratification had been reached.

In terms of the substance, the SPA deals with issues related to values and reinforces an interest in bilateral cooperation, in particular in policy areas where strategic cooperation would be beneficial to both parties such as agriculture, arctic policies, environmental, fisheries, internet-security, judicial, maritime issues, political, research and development, security, social, taxation, combatting terrorism, and of course on global economic issues (although most of the economic issues which deal with bilateral matters is dealt with comprehensively in the CETA agreement). In these areas the two sides declared to want to enhance the dialogue and where appropriate cooperate. The important issues to do with values are cooperation on issues such as human rights, democracy, the rule of law, peace and security, and so on. One of the ways, mentioned in the agreement, to ensure collaboration is to work together in various multilateral forums. The text literally states:

The Parties share a commitment to multilateralism and efforts to improve the effectiveness of regional and international fora and organisations such as the United Nations and its specialised organisations and agencies, the Organisation for Economic Co-operation and Development (OECD), the North Atlantic Treaty Organization (NATO), the Organization for Security and Co-operation in Europe (OSCE) and other multilateral fora" (SPA, article 8(1)).

Other forms of cooperation through such multilateral organisations included the International Monetary Fund (IMF), World Bank, and the various G-7 or G-20 fora. In addition, another way to enhance consultation would be through summits where leaders meet (on an annual basis) and have high-level meetings such as at the level of foreign ministers. Furthermore, consultation would be developed at the various ministerial levels depending on the policy area of 'mutual interest' (SPA article 27(1c)). In addition, Joint Ministerial Committees would be established to replace the earlier created 'transatlantic dialogue' (SPA article 27 (2b)) as well as establish a Joint Cooperation Committee.

When analysing this SPA we find a few things that are remarkable. First is that it covers a very wide range of issues. The SPA brings together so many different issues that were previously either explicitly mentioned in bilateral agreements or were considered to be of mutual interest but less well articulated in formal agreements. Second, the wording of the SPA signals a need to collaborate as much as possible in as many areas as possible, and using as much as possible the various multilateral forums in addition to having annual meetings.

In earlier attempts to complete such an agreement in the area of free trade the multilevel governance nature of the EU and of Canada was something that was hard to understand by either of the parties (Croci and Tossutti, 2009; Benz, 2010). Furthermore, the SPA only emerged when both Canada and the EU realised that they needed to diversify away from a predominant orientation towards the US (Croci and Verdun, 2004). Both sides had at different times been more focused on keeping the US on side than appreciating 
the benefits that the 'other transatlantic' partner good provide (DeBardeleben and LeBlond, 2010). Over the first half of the 2010s, the US was increasingly orienting itself towards Asia and neither Canada nor the EU were given the feeling by US diplomats that they were very 'special'. At this time, the EU was becoming more aware of the need to have its own external relations. With the EU expanding into countries (through enlargement, but also developing an European Neighbourhood Policy), it became clear to the Europeans that they shared much more with Canada than they did with these other countries that they were pulling closer (Pentland, 2009). Finally, the realization dawned on both sides that the collaboration would benefit from being, on the one hand a free trade agreement, on the other hand more 'strategic'. To keep the negotiations doable, and also given how the EU is structured in terms of competences for foreign policy versus trade issues, having these agreements discussed at two separate tables increased the chance of success across the agreements. Thus, both elements were separated. Dividing up these issues this way was something the EU had started to do (Knodt, Piefer and Müller, 2015). Having these separate issues covered by both sides was also of interest to Canada. In fact, by separating out these issues, the SPA agreement was able to be more declaratory rather than overly legal. It also meant that the trade agreement could remain separate. Having the SPA meant updating the 1976 agreement so as to cover a much broader range of issues.

\section{Conclusion}

Having reviewed the four periods of EU-Canada cooperation, this article is now in a position to provide an answer to the core question that is addressed here: why was it possible to sign an SPA, in 2016 but not before? In answering this question the paper looked at why the deepening of the EU-Canada strategic partnership had been a challenge to set up in the first three decades after having signed early institutional structure provided by the 1976 agreement. In providing an answer to the overarching question raised here, this paper took stock of the various agreements that have been made in the period since the 1950s. It looked among other things at the role of the agreements that had been signed.

The literature reviewed suggested that, among other things, earlier cooperation in this domain after 1976 mostly consisted of sectoral agreements in part because Canada and the EU had not yet identified the Canada-EU partnership as important to the international well-being of either side, whether this was economic, security, or otherwise. Each of them relied on cold war legacies with the US being the dominant partner in the transatlantic alliance and neither of them considering the need for an institutionalised bilateral agreement separate from the US as absolutely crucial. Clearly, during the first and second time periods, (that is, respectively 1959-1976 and 1977-1996) the international context was still characterised as bipolar with the Soviet Union and its partners versus the US and the western partners with all of them collaborating on security matters through NATO. Furthermore the institutional structure of the EU was still less developed compared to what it became with the entry into force of the Maastricht Treaty (November 1993) and later the Lisbon Treaty (December 2009). The EU was a unitary actor only in the area of commercial relations, not in the area of foreign relations, but both treaties contributed to a further institutional development of the EU as a foreign actors. Indeed, even to this day, the EU is only as strong in foreign relations as the agreement that can be mustered among the member states. Yet, the Lisbon Treaty has provided the EU with a bit more bureaucratic and institutional apparatus to make it easier to work on what the EU is about in terms of foreign relations. Thus, the reason 
that the strategic partnership and the CETA could be signed in 2016 has both an endogenous and an exogenous component. Endogenous in that both Canada and the EU were realising that they were internally needing to diversify and become less reliant on the US. In the case of the EU, the institutional structure of the EU had changed with the Lisbon Treaty. In Canada, its experience with the failed trade agreement with the EU in the 200os had brought about a realisation that any agreement like this needed stronger buy-in from lower level governments. Exogenous factors was a move of the US away, gradually, from that of a reliable transatlantic partner that was keen on multilateralism with a strong allegiance to Canada and the EU, towards an orientation increasingly more towards the rising powers of the rest of the world. Neither Canada nor the EU were receiving strong signals from the US that they were an 'important' or 'preferred' partners. Thus it became easier to do a bilateral deal together. Furthermore, each of these polities needed the experience of the prior decades to learn that the other side was governed institutionally in a loosely federal way. Each of them had veto players among them that needed to be catered to, and thus any negotiation between both sides needed to be undertaken very carefully with full attention to the many voices around the table. Because of these factors, neither side was keen to work on a comprehensive agreement prior to the fourth period. In fact, during the third period there could have been a deeper free trade agreement but it did not materialise in part because on the Canadian side the federal level was unable to commit the lower levels to a joint agreement. Thus, the SPA (together with the CETA that was signed at the same time and covered other ground) became the most comprehensive set of agreements that the EU signed with another major advanced economy. It includes various dimensions: agriculture, arctic politics, environmental, fisheries, internet-security, judicial, maritime issues, political, research and development, security, social, taxation, combatting terrorism, and of course global economic issues. As we look towards the next period we await a few developments: first, whether all member states will ratify the SPA agreement; and second, what the Agreement will lead to in practice. Only time will tell whether the framework offered will provide the collaboration those who drafted the agreement had in mind.

\section{References}

Barry, Donald (1998) “The Canada-European Union Turbot War. Internal Politics and Transatlantic Bargaining”, International Journal 53(2): 253-284.

Barry, Donald (2004) “Towards a Canada-EU Partnership?”, in Patrick Crowley (ed.) Crossing the Atlantic: Comparing the European Union and Canada, Aldershot: Ashgate Publishing: 35-60.

Barry, Donald, Appelbaum, Bob, and Wiseman, Earl (2014) Fishing for A Solution: Canada's Fisheries Relations with the European Union, 1970-2013, Calgary: Calgary University Press.

Benz, Arthur (2010) "Multilevel parliaments in Canada and Europe", International Journal, 66(1): 109-126.

Bernard-Meunier, Marie (2006) "Did you Say Europe? How Canada Ignores Europe and Why That is Wrong", in Andrew Cooper and Dane Rowlands (eds.), Canada Among Nations 2006, Montreal: McGill University Press: 109-124.

Biscop, Sven (ed.) (2013) The Routledge Handbook of European Security, London: Routledge. 
Commission of the European Communities (2003) "Communication from the Commission on EU-Canada relations" COM (2003) 266 final, 13.05.2003.

Conference Board of Canada and MGK International Trade Consultants (1998) Facilitating Trade and Investment Between Canada and the EU: A Strategy for Moving Forward, Ottawa/United Kingdom: Conference Board of Canada/MGK International, May.

Croci, Osvaldo and Tossutti, Livianna (2007) "That Elusive Object of Desire: Canadian Perceptions of the European Union”, European Foreign Affairs Review 12(4): 287-310.

Croci, Osvaldo and Tossutti, Livianna (2009) "Canada and the EU: A Story of Unrequited Attraction" in Laursen, Finn (ed.) The EU in the Global Political Economy, Brussels: PEI Peter Lang.

Croci, Osvaldo and Amy Verdun (2004) "Searching for a Counterweight-Canada and the European Union.” Jean Monnet/Robert Schuman Paper Series 4(12): 1-11.

https://eucenter.as.miami.edu/ assets/pdf/crociverdunfinal.pdf [accessed: 19 January 2020].

Croci, Osvaldo and Amy Verdun (2006) "Security challenges in the 21st century: EU, USA, and Canadian approaches." Policy workshop, The Transatlantic Security Triangle: Where Does Canada Fit? Ottawa, June 12, 2006. https://carleton.ca/canadaeurope/wpcontent/uploads/Croci-Verdun19-June2006.pdf [accessed: 19 January 2020].

Croci, Osvaldo and Amy Verdun (2007) "Canada: Taking security seriously after 11 September?”, in Kirchner, Emil and Sperling, James (eds), Global Security Governance: Competing Perceptions of Security in the 21st Century, London: Routledge: 137-160.

Crowley, Patrick M. (ed.) (2004) Crossing the Atlantic: Comparative EU-Canadian Studies, London: Ashgate.

DeBardeleben, Joan and Patrick Leblond (2010) "The other transatlantic relationship: Canada, the EU, and 21st-century challenges", International Journal, 66(1): 1-7.

Dolata-Kreutzkamp. Petra (2010) "Drifting Apart? Canada, the European Union and the North Atlantic", Zeitschrift fur Kanada-Studien, 30(2): 28-44.

European Union (2017) "EU-Canada Strategic Partnership Agreement' Factsheets", Brussels 01/04/2017, Unique ID: 161029_11.

Fenton Cooper, Andrew (1994) "Canada-EC Relations in Comparative Perspective: Promise, Problems and Prospects”, in MacMillan, Gretchen (ed.), The European Community, Canada and 1992, Calgary: The University of Calgary Press.

Gardner, Andrew (2014) "EU and Canada move closer to strategic partnership agreement”, Politico, 11 September.

Government of Canada and European Commission (2008) Assessing the costs and benefits of a closer EU-Canada economic partnership. A Joint Study by the European Commission and the Government of Canada.

Haglund, David G. and Frédéric Mérand (2010) "Transatlantic relations in the new strategic landscape: implications for Canada”, International Journal 66(1): 23-38.

Howe, Brendan and Matthew Kerby (2009) "The Canada-EU Turbot War of 1995 and the Cybernetic Model of Decision-Making”, The Round Table, 98(401): 161-179, DOI: 10.1080/00358530902757883. 
Hübner, Kurt (ed.) Europe, Canada and the Comprehensive Economic and Trade Agreement, London: Routledge.

Kagan, Robert (2003) Of Paradise and Power: America and Europe in the New World Order, New York: Alfred A. Knopf.

Knodt, Michèle, Nadine Piefer and Franziska Müller (eds.) Challenges of European External Energy Governance with Emerging Powers, Farnham: Ashgate.

Long, David (2003) “Transatlantic Relations and Canadian Foreign Policy”, International Journal 58(4): 591-614.

Mace, Gordon and Gérard Hervouet (1989) “Canada’s Third Option: A Complete Failure?”, Canadian Public Policy, 15(4): 387-404.

Mahant, E. E. (1976) "Canada and the European Community: The New Policy”, International Affairs, 52(4): 551-564.

Mahant, Edelgard (1981) "Canada and the European Community: The First Twenty Years”, Journal of European Integration 4(3): 263-279.

Mahant, Edelgard (1985) "Institutional Aspects of Canada-European Community Relations”, Canadian Yearbook of International Law, 23: 285-296.

Mérand, Frédéric and Rayoux, Antoine (2018) "Foreign, security and defence policies", in Brunet-Jailly, Emmanuel, Hurrelmann, Achim, and Verdun, Amy (eds). European Union Governance and Policy-Making: A Canadian Perspective, Toronto: University of Toronto Press.

Mérand, Frédéric and Vandemoortele, Antoine (2011) "Europe's Place in Canadian Strategic Culture (1949-2009)”, International Journal, 66(2), 419-438.

Missios, Paul C. and Charles Plourde (1996) "The Canada-European Union Turbot War: A Brief Game Theoretic Analysis”, Canadian Public Policy 22(2): 144-150.

Muirhead, Bruce (2004) "From Special Relationship to Third Option: Canada, the US and the Nixon Shock", American Review of Canadian Studies, 34(3): 439-462.

Pentland, Charles (2004) "Odd Man in: Canada and the Transatlantic Crisis", International Journal, 59(1): 145-166.

Pentland, Charles (2009) "Enlargement: Expanding the Realm of European Governance", in Tömmel, Ingeborg and Verdun, Amy (eds.) Innovative Governance in the European Union: The Politics of Multilevel Policymaking, Boulder: Lynne Rienner publishing.

Potter, Evan (1999). Transatlantic Partners: Canadian Approaches to the European Union, Montreal and Kingston: McGill-Queen's University Press.

Rayroux Antoine (2018) The EU's Reputation in Canada: Still a Shallow Strategic Partnership?, in Chaban, Natalia and Holland, Martin (eds.) Shaping the EU Global Strategy. The European Union in International Affairs, Basingstoke: Palgrave Macmillan, pp. 55-75.

Rudd, David (2010) "The Future of Transatlantic Relations: A View from Canada”, in Dorman, Andrew M. and Kaufman, Joyce P. (eds) The Future of Transatlantic Relations: Perceptions, Policy and Practice, Stanford: Stanford University Press. 
Selen, Sarisoy Guerin and Napoli, Chris (2008) "Canada and the European Union: Prospects for a Free Trade Agreement," Centre for European Policy Studies (CEPS) Working Document No. 298, July.

Tossutti, Livianna, Croci, Osvaldo and Verdun, Amy (2007) "National Threat Perception: Survey Results from Canada", in Kirchner, Emil and Sperling, James (eds), Global Threat Perception: Elite Survey results from Canada, China, the European Union, France, Germany, Italy, Japan, Russia, the United Kingdom and the United States, GARNET Working Papers No. 18/07.

Vanderkooy, Jake (z1996) “Chornique d'actualité/Current developments”, Journal of European Integration, 19(2-3): 247-264, DOI: 10.1080/07036339608429040.

Wood, Donna E. and Amy Verdun (2010) "Canada-European Union Relations: A review of the literature from 1982 to 2010”, International Journal 66(1): 9-21. 